\title{
Task-Based Language Teaching in Developing Marine and Fisheries Students' Speaking Skill (A Study in SUPM Negeri Ladong, Aceh)
}

\author{
Ikhwan Wahidin \\ marwanwahidin@yahoo.co.id
}

SUPM Negeri Ladong, Aceh, Indonesia

\begin{abstract}
The objective of the research were (1) To obtain an empirical evidence for the lack of knowledge we have right now about how TBLT is used in developing Marine and Fisheries students' English speaking proficiency. (2) To find out students' perceptions on the implementation of TBLT whether learning with TBLT is helpful to understand the lesson or not. The research method was quasi experimental. This research assigned two groups, experimental and control group. Each group consisted of 25 students. The sample was chosen by applying purposive sampling technique. The data obtained through the test were analyzed by using descriptive and inferential statistic. Then the data on the students' perception in learning speaking by using TBLT approach was collected through questionnaire. The research result showed that there was a positive development on the students' speaking achievement. It was proved by the mean score of the students' posttest in experimental group that showed 67.64 while the mean score of the students' posttest in control group was 56.08. It means that there was a positive development in experimental group. With those several benefits, TBLT ensures that students have a high positive perception. It was proved with majority students' perception which is $76 \%$. It was classified as high and it can be concluded that TBLT is helpful approach.
\end{abstract}

Key word : Task-Based Language Teaching, Marine and Fisheries' Speaking Skill.

\section{INTRODUCTION}

In teaching there are a lot of challenges that teachers have to deal with especially in English teaching as a foreign language. Among four skills taught in the class namely speaking, listening, writing, and reading, speaking is more challenging to teach and apply by the students in the class. Burn and Joyce (1997) described that speaking is interactive process of constructing meaning that involves producing and receiving and processing information. So, teaching speaking is not merely to let students to repeat and memorize dialogues, but they should be able to use the utterance to communicate in the real situation. 
Wahidin : Applying Task-Based Language Teaching ... |141

There are a lot of activities that teachers do to develop students' speaking skill such as presentation, short conversations, role play, and memorizing words but remain give un-satisfied result whereas speaking is the most important skill in communication (Zaremba, 2006) because speaking is the most used skill in our daily activity more often than reading and writing (Bahrani, 2011).

One of the approaches that is assumed can develop students' skill is Task-Based Language Teaching (TBLT). According to Ellis (2003), TBLT is approach that use language in real situation setting not as an object for study. So, it will be better if the language is applied in form of real setting practice.

The basic principal of TBLT is creating and put students into situation and activities where they will use their language skill actively (Alsagheer \& Hasan, 2014). It is believed that the effective way to teach language is by engaging the students in real language use in the classroom. Wilis and Wilis (2007) mentioned some important things in TBLT. They focus TBLT in order to provide the students a lot of opportunities to use the language in pair work, group work or teacher fronted methodology. So, the students have confidence and willingness to develop the language they have already had.

Some researchers have done investigation related to TBLT in varios parts of language teaching. Muhammadipour and Rashid (2015) and Boonkit (2010) found that TBLT provided opportunities for the students to speak in different situation and expressed them freely and also became the centre of the learning process. Furthermore, the students plan their speaking and interaction among them in English as an effective way in developing their skills (Muhammadipour and Rashid, 2015). Moreover, Tabrizi \& Nasiri (2011) did a research to investigate the effect of TBLT on speaking ability. The study claimed that TBLT enhance students' fluency and accuracy because their well motivated. TBLT also develop students' comprehension because meaning negotiation.

Teachers in SUPM actually have applied many kinds of tasks during teaching-learning process but applications of the tasks are not yet using systematic pattern like TBLT offered. In this research, the researcher introduced TBLT concept to students to maximize application of tasks in the school. The three phases that are proposed by Willis was used in the research. The form of the tasks that usually applied in SUPM are not related with students' background but in this research, the tasks were provided related to Marine and Fisheries students' context and those tasks were designed in line with real life usage in this context. Teachers' role that used to be teacher-centered was changed to students-centered such suggested by TBLT framework. 


\section{2| ELT Worldwide Vol. 3 No.2 October 2016}

These are the aspects that have not been covered by the previous research. In addition, there were several problems that appeared in developing speaking skill in SUPM. One of the biggest problems was lacking of basics English knowledge such as less vocabulary and grammar. The second problem was most of the students shy and nervous when asked to speak English. Because of those conditions, students' speaking achievements in SUPM could be classified as low.

Based on all explanations above, the researcher conducted research to find out students' developments in speaking skill that used TBLT as approach and students' perception toward TBLT approach. By knowing all of those a better program could be developed and conducted in SUPM especially developing students' speaking skill.

\section{METHODS}

This research employed a quantitative approach with a quasi-experimental design with two groups' pre-test and post-test. This design used a nonequivalent control group design. It had treatment group that would be given a pretest, a series of treatments, and a posttest. One group was randomly assigned to the experimental group and the other was assigned to the control group.

These research variables consist of one independent variable and two dependent variables. The dependent variables were students' speaking skills development and students' perception. Students' speaking skills development deal with accuracy, fluency, comprehensibility and the other was students' perception. The independent variable was Task-based Language Teaching. Students performed their argument or idea involving critical thinking process. There were some methods applied and the topics must be on students' knowledge background.

The researcher classified the population first by listing down all members of population. The total number of students was 350 students in academic year 2014-2015. In this research, the population was around 50 students taken from TBP A and TBP B at SUPM Negeri Ladong Aceh. Based on the population, the researcher used cluster random sampling and the sample was taken from first grade of TBP. One of two groups was chosen as experimental group and the other was as control group (TBP B as the experimental group and TBP A as the control group). Numbers of all samples were two classes and 50 students; 25 students of TBP B were in experimental group and 25 students of TBP A were in control group. Dealing with the sample size of experimental research, 50 students were representative enough to be the sample of this research. 
In collecting the data, the researcher used two kinds of instruments namely speaking test and questionnaire. Speaking test consisted of a pretest and a posttest. The students were given a piece of paper that contained several topics and students were free to choose one topic to be presented it in front of the audience (oral presentation). The form of question in pretest was similar with posttest. In this research, questionnaire was given to find out the students' perception toward the application of TBLT. The questionnaire used Likert Scale. There were 24 questions given to the students to cover the students' perception in the implementation of TBLT.

In the first week, the researcher conducted a pretest in speaking in order to know the students' proficiency and to find out their scores. The pretest ran for two hours. It was conducted outside the hour of lecture or it was implemented by using extra time one week before conducting treatment where each student had three minutes to speak. The researcher provided several topics but they had to choose one of them. The researcher recorded the speaking activity and made transcription to find out more accurate data of students' proficiency. The treatment was conducted in 10 meetings. Each meeting ran in 90 minutes. In those meetings, the researcher used a problem solving task, sharing personal experience task, presentation task, role play task, and opinion exchange task. The procedure in giving the treatment was appropriate with lesson plan that made before. At the end of the meeting, the researcher conducted a posttest. The posttest ran for two hours. It was conducted outside the hour of lecture or it was implemented by using extra time one week after conducting treatment where each student had three minutes to speak. The researcher provided several topics but they had to choose one of them. The researcher recorded that the speaking activity and made transcription to find out more accurate data of students' proficiency. Data on students' speaking test were collected in line with the instrument (test and questionnaire). The data were analyzed by using the following procedure:

1. Speaking test

The students answer from the test was transcribed. The transcription will be analyzed using the following criteria level introduces by Heaton (1989: 100). Then obtained scores were analyzed by using the following steps;

a. Converting the score

b. Classifying the score of the students into seven level as follow: 
Table 3.4 The Scoring Classification of the Students Speaking Skill.

\begin{tabular}{lcc}
\hline No. & Score & Classification \\
\hline 1. & $90-100$ & Very Good \\
2. & $70-89$ & Good \\
3. & $50-69$ & Fair \\
4. & $30-49$ & Poor \\
5. & $\leq-29$ & Very Poor \\
\hline
\end{tabular}

c. Calculating the Mean Score, Standard Deviation and t-test value

To find out students' mean score, standard deviation and t-test value between pre-test and post-test both classes, the researcher was used Statistical Package for Social Science (SPSS) program version 20.0.

\section{Questionnaire}

The questionnaire was given to the students by using the Likert scale. The aim was to ask the samples to respond to a series of statements by indicating whether one strongly agree (SA), agree (A), undecided (U) disagree (D), and strongly disagree (SD) with the statements will be given.

Each response was associated with a point value and an individual score was determined by summing the point value for each statements. The point values were assigned to response to the positive statements. For negative statements, the point values were reversed. The data were analyzed as follows:

Table 3.5 Likert Scale

\begin{tabular}{ccc}
\hline $\begin{array}{c}\text { Positive statement } \\
\text { score }\end{array}$ & Category & $\begin{array}{c}\text { Negative statement } \\
\text { score }\end{array}$ \\
\hline 5 & Strongly Agree & 1 \\
4 & Agree & 2 \\
3 & Undecided & 3 \\
2 & Disagree & 4 \\
1 & Strongly Disagree & 5 \\
\hline & & (Arikunto, 2006:229)
\end{tabular}

To interpret the students' perception, the research used classification system. The questionnaire employed 5 categories and the rating score from 20 to 100 in determining the level of students' perception on TBLT. The interval rating score of the students' responses can be shown as follows: 
Table 3.6 The scoring Classification of the Students' perception

\begin{tabular}{ccc}
\hline No. & Interval Score & Classification \\
\hline 1 & $81-100$ & Very High \\
2 & $61-80$ & High \\
3 & $41-60$ & Moderate \\
4 & $21-40$ & Low \\
5 & $0-20$ & Very Low \\
\hline
\end{tabular}

Measures of frequency (descriptive statistics) method were used in calculating the percentage of the students' perception through SPSS 20.0 .

\section{FINDINGS}

The findings of this research deal with students' score in speaking which cover students' accuracy, fluency, and comprehensibility and students' perception. Students' speaking score is described in four parts namely the frequency and percentage of the students' speaking score, the mean score and standard deviation of students' speaking score, the overall students' speaking score and test of significance. Then, it is continued with students' perception toward the use of TBLT Approach.

A. Students' Speaking Ability.

1. The Frequency and Percentage of the Students' Speaking Score

a. Scoring Classification of the students' Pretest in experimental and control group.

Table 4.7. The percentage of students' speaking ability in pretest of experimental and control group.

\begin{tabular}{cccccc}
\hline \multirow{2}{*}{ Classification } & \multirow{2}{*}{ Score } & \multicolumn{2}{c}{ Experimental Group } & \multicolumn{2}{c}{ Control Group } \\
\cline { 3 - 6 } & & Frequency & Percentage & Frequency & Percentage \\
\hline Very Good & $90-100$ & & & & \\
Good & $70-89$ & & & & \\
Fair & $50-69$ & 7 & 28 & 8 & 32 \\
Poor & $30-49$ & 16 & 64 & 10 & 40 \\
Very Poor & $\leq-29$ & 2 & 8 & 7 & 28 \\
\hline Total & & 25 & 100 & 25 & 100 \\
\hline
\end{tabular}

Table above shows that most of students are in low achiever level. In experimental group, $7(28 \%)$ students are categorized as fair, 16 $(64 \%)$ students categorized as poor and $2(8 \%)$ students categorized as very poor. Meanwhile, in control group, 8 (32\%) students are categorized as fair, $10(40 \%)$ students are categorized as poor, and 7 $(28 \%)$ students are categorized as very poor. 
146 ELT Worldwide Vol. 3 No.2 October 2016

Based on the result above, it shows that the ability of students of experimental group before giving treatment by using TBLT and ability of students of control group are almost same.

b. Scoring Classification of the students' Posttest in experimental and control group

Table 4.8. The percentage of students' speaking ability in posttest of experimental and control group.

\begin{tabular}{cccccc}
\hline \multirow{2}{*}{ Classification } & \multirow{2}{*}{ Score } & \multicolumn{2}{c}{ Experimental Group } & \multicolumn{2}{c}{ Control Group } \\
\cline { 3 - 6 } & & Frequency & Percentage & Frequency & Percentage \\
\hline Very Good & $90-$ & & & & \\
Good & 100 & & & 4 & 16 \\
Fair & $50-89$ & 10 & 40 & 13 & 52 \\
Poor & $30-49$ & 13 & 52 & 8 & 32 \\
Very Poor & $\leq-29$ & 2 & 8 & & \\
\hline Total & & 25 & 100 & 25 & 100 \\
\hline
\end{tabular}

The table 4.8 above illustrates that the result of posttest of experimental group was none $(0 \%)$ of students got very poor and very good, $10(40 \%)$ students got good, 13 (52\%) students got fair, and $2(8 \%)$ students got poor. Meanwhile, posttest result of control group was none $(0 \%)$ of students got very poor and very good, 4 (16\%) students got good, $13(52 \%)$ students got fair, and $8(32 \%)$ students got poor.

2. The Mean Score and Standard Deviation of the Students'

Pretest and Posttest in Speaking.

Table 4.12. The mean Score and Standard Deviation of the Students' Pretest and Posttest in Speaking.

\begin{tabular}{cccccc}
\hline \multirow{2}{*}{ Speaking } & \multicolumn{5}{c}{ Group Statistics } \\
\cline { 2 - 6 } & Group & \multirow{N}{*}{} & Mean & $\begin{array}{c}\text { Std. } \\
\text { Deviation }\end{array}$ & $\begin{array}{c}\text { Std. Error } \\
\text { Mean }\end{array}$ \\
\hline \multirow{2}{*}{ Experimental } & Pretest & 25 & 41.68 & 11.982 & 2.396 \\
\multirow{2}{*}{ Control } & Posttest & 25 & 67.64 & 9.582 & 1.916 \\
& Pretest & 25 & 39.76 & 12.985 & 2.597 \\
& Posttest & 25 & 56.08 & 11.206 & 2.241 \\
\hline
\end{tabular}


Table 4.12 shows that there is a positive development among groups. The table shows that the mean score of the students' pretest in experimental group was 41.68 and standard deviation was 11.982 and in posttest was 67.64 and standard deviation was 9.582. Meanwhile, the table shows that the mean score of the students' pretest in control group was 39.76 and standard deviation was 12.985.In posttest, the mean score was 56.08 and standard deviation was 11.206. The mean score of both pretest and posttest improved after both groups receive the treatment. It means that the mean score of posttest is higher than pretest $67.64>41.68$ and $56.08>39.76$. The table also shows that the mean score of students' pretest of experimental class was 41.68 and control class was 39.76. Based on the table above, it can be concluded that the students mean score of experimental class was statistically the same with control class.

The mean score of students' posttest of experimental class was 67.64 and control class was 56.08. It means that the mean score of experimental class is higher than control class $(67.64>56.08)$ and standard deviation for experimental class was 12.852 and control class was 12.932. It showed that after giving the treatment, the result of experimental class on the mean score was higher than the control class. It can be concluded that the experimental class taught by applying TBLT shows significant development toward the students' ability in speaking than students treated by implementing conventional method.

\section{Test of Significance (t-test)}

The hypotheses were tested by using inferential analysis. In this case. the researcher used t-test (testing of significance) for independet sample t-test, that is, a test to know the significant comparison scores of posttest on both experiment and control groups before and after giving treatment.

Before analyzing the t-test, the researcher put the level of significance or $(\alpha)$ in 0.05 , and the degree of fredom (df) using formula $\mathrm{N}_{1}+\mathrm{N}_{2}-2$ in which the sample of this research is 50 . Hence, the $\mathrm{df}$ is 48 derived from $25+25-2$. After analyzing the $\mathrm{t}-$ test, the researcher obtained the data as the following table:

Table 4.15 The P-Value of the Students' Speaking.

\begin{tabular}{lccc}
\hline \multicolumn{1}{c}{ Variables } & $\begin{array}{c}\text { Probability } \\
\text { Value }\end{array}$ & $(\alpha)$ & Remarks \\
\hline $\begin{array}{l}\text { Pretest of Experimental and } \\
\text { Control Group }\end{array}$ & 0.589 & 0.05 & $\begin{array}{c}\text { Not significantly } \\
\text { different }\end{array}$ \\
\hline $\begin{array}{l}\text { Posttest of Experimental and } \\
\text { Control Group }\end{array}$ & 0.000 & 0.05 & $\begin{array}{c}\text { Significantly } \\
\text { different }\end{array}$ \\
\hline
\end{tabular}




\section{8| ELT Worldwide Vol. 3 No.2 October 2016}

Table 4.15 shows that in pretest of experimental and control group, the $p$ value was 0.589 greater than $\alpha 0.05$. It means that in pretest of both groups there was no significant difference but in posttest the value of $p$ value was 0.000 smaller than $\alpha 0.005$. It means that there was a significant different between the groups. The researcher presents the signifficant difference between experiment and control groups for posttest as shown on table 4.15 above. The researcher found that the probability value was smaller than the level of significance ,05 $(, 000<, 05)$. It indicated that $\mathrm{H}_{0}$ was rejected and $\mathrm{H}_{1}$ was accepted. It means that there was a significant difference between posttest of experiment and control group after treated by using TBLT in SUPM Negeri Ladong, Aceh. It was completely different from the control group in which the students' speaking ability was not significantly different since the researcher only used conventional method in teaching speaking to the students.

The data shown in table 4.16 below indicated the achievement of experimental class and control class before and after giving the treatment.

Table 4.16 The Comparison of T-value and T-table of the students'

\begin{tabular}{lccc}
\multicolumn{4}{c}{ Speaking Achievement. } \\
\hline \multicolumn{1}{c}{ Variables } & T-Value & T-Table & Remarks \\
\hline $\begin{array}{l}\text { Pretest of Experimental } \\
\text { and Control Group }\end{array}$ & 0.543 & 2.010 & $\begin{array}{c}\text { T-Value is } \\
\text { lower than T- } \\
\text { Table }\end{array}$ \\
\hline $\begin{array}{l}\text { Posttest of Experimental } \\
\text { and Control Group }\end{array}$ & 3.920 & 2.010 & $\begin{array}{c}\text { T-Value is } \\
\text { Higher than T- } \\
\text { Table }\end{array}$ \\
\hline
\end{tabular}

The table 4.16 shows that the $t$-value was 0.543 with degree of freedom 48 and $P$ value 0.000 . From the degree of freedom it can be known the $t$-table of this research was 2.010. Based on the data, the $t$-value $(0.543)<t$-table $(2.010)$ and $P$ value $(0.589)>0.05$. In pretest, there is no significant difference between two groups' score because the $P$ value higher than 0.05 (0.589>0.05). It means that $\mathrm{H}_{0}$ was accepted and $\mathrm{H}_{1}$ was rejected in pretest. In other word, the students' ability or level is same before giving the treatment.

The table 4.16 above shows that the $t$-value was 3.920 with degree of freedom 48 and $P$ value 0.000 . From the degree of freedom it can be known the $t$-table of this research was 2.052. Based on the data, the $t$-value (3.920)> t-table (2.010) and $P$ value $(0.000)<0.05$. In posttest, there is a significant difference between two groups' score because the $P$ value was less than $0.05(0.00<0.05)$. 
Wahidin : Applying Task-Based Language Teaching ... 149

It means that $\mathrm{H}_{1}$ was accepted and $\mathrm{H}_{0}$ was rejected in posttest. In other words, there was a significant difference of the students' score between both groups after receiving treatment.

From that finding, the researcher can conclude that TBLT is more effective than Conventional Method to enhance students' speaking skill achievement.

\section{Students' Perception}

The questionnaires were distributed to the students to know their perception toward Task-Based Language Teaching approach in teaching speaking at TBP B SUPM Negeri Ladong Aceh. The students' score interval of questionnaire can be shown in table below:

Table 4.17. Percentage of the Students' perception toward Task-Based Language Teaching.

\begin{tabular}{|c|c|c|c|}
\hline \multirow{2}{*}{ Interval Score } & \multirow{2}{*}{ Category } & \multicolumn{2}{|c|}{ Perception toward TBLT } \\
\hline & & $\mathrm{F}$ & $\%$ \\
\hline $81-100$ & Very High & 1 & 4 \\
\hline $61-80$ & High & 19 & 76 \\
\hline $41-60$ & Moderate & 5 & 20 \\
\hline $21-40$ & Low & - & - \\
\hline $0-20$ & Very Low & - & - \\
\hline \multicolumn{2}{|c|}{ Total } & 25 & 100 \\
\hline
\end{tabular}

The data of the students' interval score on the questionnaire in table 4.17 indicates that the use of TBLT in teaching speaking was very interested, it shows that 1students (4\%) felt strongly positive, 19 students $(76 \%)$ felt positive, 5 students $(20 \%)$ felt moderate and none of the students felt negative and strongly negative. It means that TBLT is a helpful approach according to the students. It is emerging a good perception among the students.

\section{DISCUSSION}

This section deals with the interpretation of the findings derived from the result of statistical analysis and also the description of data gained from the questionnaire based on students' perception toward TBLT. 
150| ELT Worldwide Vol. 3 No.2 October 2016

\section{Classroom Situation}

a. Pre-Task stage

In the beginning, the students were not interested in this approach. The next step that was done by the researcher was inviting the students who had been shown videos or few pictures for the topic to be talked about later.

This matter eventually increased students' awareness in studying. Further when the researcher did words games that also related to the topic. Improving students' awareness with interesting exercises such as watch recording, words game, listing words and mind map turned out to be very effective way. In addition, this stage also improves students' awareness in understanding appropriate grammatical rules and gains a lot of new words that related to the topics. This result was in line with research that held by Muhammadipour and Rashid (2015) who state that pre-task stage improves students' language knowledge such as their structure and vocabulary. Besides, it encourages the students to use it properly.

In this stage, students who had low confident due to the low vocabulary and grammar achievement were helped because this stage gave students chance to recall their old vocabulary, learn new vocabulary, and learn how to pronounced it well. In line with above result, Ho and Long (2014) explain that there are two factors that influence students' speaking skill. The two factors are lack of vocabulary and grammar. Furthermore, they claim that TBLT has a huge impact to minimize those negative factors.

b. During Task Stage

In this stage, the students were given pair or group exercises where students helped each other to complete the tasks that were given by the researcher. They worked together to achieve goals of the tasks. In this task, students prepared their report and practiced each other. The researcher helped students to correct their mistake on the report in term of linguistic and how to perform their report later.

Pairs or group exercises gave students chance to decrease their communicative pressure, increase their confident and at last increase their accuracy and fluency when they speak. It proved that in their accuracy and fluency improving significantly. After done with their reports, the groups would present in front of the class and other groups compare their result. In this stage, students learned from other group and discuss other group result with their members so they could get new knowledge from those groups such as new words, phrases, grammar pattern, and how to choose correct words that appropriate to social context. 
Wahidin : Applying Task-Based Language Teaching ... |151

c. Post-Task Stage

In this stage, the students included the researcher to evaluate the mistakes that appear in the transcript of the recording that took before.

When the researcher discuss with the students, they could use the grammar, words and other knowledge that they gained before to support their completion of the report. The use of video recording to the students felt supportive because they can see their own video speaking report and enable them to identify their own speaking problems. After knowing the mistakes, the researcher arranged practice of new words and patterns that appear in the data.

\section{Speaking Ability}

a. The Students' Speaking Accuracy

The use of Task-Based Language Teaching (TBLT) in Experimental group gained a better result than conventional way in control group in the students' speaking performance in term of accuracy. However, it cannot be denied that first grade TBP B in the year 2015 academic year made some mistakes during the research. The mistakes that the students made were exemplified in the following description.

\section{1) Mispronunciation}

One of the most important components in good English is pronunciation. To have a good communication, it is necessary to have it. In fact, most of students made some mistake in pronouncing some English words. The researcher found that students had difficulty to pronounce some English words because they were mostly influenced by the use of their mother tongue. This is in line with Dailey (2009) argues that the students frequently use a lot of mother tongue if they do not have sufficient vocabulary and English language knowledge.

\section{2) Grammatical Error}

One of the most important things in effective communication is having enough English language knowledge and one of those important things is grammar. The lack of grammar could influence students in speaking. Several grammar mistakes that made by the students were usually related to omit plural form, omit to be, error in word order, mostly used present tense even though the sentences must use other tenses. . Even though there were still few mistakes that did by the students in posttest, TBLT apparently reduced students' grammatical error. 


\section{2| ELT Worldwide Vol. 3 No.2 October 2016}

\section{3) Inappropriate Word Choice}

One of the most mistakes that were usually done by the students was using inappropriate words or even mother tongue words. There were a lot of mistakes occurred before the treatment.

After the treatment, those mistakes were decreased because they had more times to prepare their speaking knowledge. In line with that statement, Boonkit (2010) writes that preparation in TBLT became an effective strategy in speaking task.

\section{4) Using other language words}

When this program taking place most of students did not speak English completely. Most of them use English mixed with Bahasa or their native language. The usage of complete English actually expected to use by the students as directed by TBLT approach but ones more the lack of vocabulary, grammar and less of willingness to speak made them used mix English but eventually the use of mother tongue and Bahasa helped the students to complete their tasks or getting meanings.

\section{b. The Students' Speaking Fluency}

In the treatment, the students practiced to be fluent to use English words in sentences. They repeated the sentences several time with the researcher and also together with their friends to get smooth flow of speech. However, most of them still made too many pauses, halting, and repeated words several times. The researcher found that the lack of grammatical pattern and vocabulary become most of their problems. In line with this finding, Sabil (2014) stated that the lack of students' vocabulary and their grammar barred the students to speak fluently.

However, implementing TBLT made the students speak bravely and expressively. The benefit of this approach is the students can express their ideas freely without considering grammar in first time. In line with the statement of Muhammadipour and Rashid (2015) who claim that TBLT gives the students chance to express themselves freely and become the centre of learning process. They speak freely with their friends, share ideas and exchanges information to their friends. The students' inhibition in speaking fluency is as follow:

1) Unnatural pauses. It is a pause the speaker makes when he wants to say something but he loses of words or of the though he wants to express. 
Wahidin : Applying Task-Based Language Teaching ... $\mid 153$

2) Deliberate halting. It is a stop talking and it is because the speaker does not know what to say.

3) Repeating word. It is a word that the speaker always almost all the time repeats the same word to get what say.

c. The Students' Speaking Comprehensibility

During the treatment, the researcher found that the students' lack of vocabulary and grammar mastery became the main reason why their sentences usually could not be understood by the researcher and their friends. Several mistakes that found by the researcher was also caused by the students did not know how to pronounce the words correctly and did not know how to manage those sentences well so the researcher had to listen carefully to know what they said. In line with the statement argued by Sabil (2013) who states that the lack of students' English vocabulary and grammar knowledge distracted the students to speak fluently. Besides, the lack of phrases and idiom mastery makes them misunderstand and misinterpret the phrases in sentences.

Based on all explanations above, the researcher concludes that the use of TBLT in developing students' speaking skill was effective even though there were still few mistakes found. The use of tasks to provide students opportunities to speak in full English was achieved even though most of the students still used their mother tongue or Indonesian words to get their message across. The use of TBLT with some flexibility in term of study eventually helps the students to achieve the objectives of training.

\section{Students' Perception}

The students stated that the program helped them to develop their English in the different way where they can speak freely without considering grammatical rules at first and together with the researcher and other students fix their mistakes and tried over and over again until they felt they had their best performance. Furthermore, Pairs and group working design made them reduce their anxiety, shyness and also improve their self confident. Based on the students' performance, the researcher saw the use of exercises that closely related to the students' knowledge and experiences had a huge impact on students' performance in speaking. In posttest, most of the students did not wonder any more to find their story pattern even though few of them still did that. The application of watching videos or seeing few pictures and words games also became a reason why the students have a high perception to TBLT. Most of them like to join the class because they were given a clue before they entered the task stage. 


\section{4| ELT Worldwide Vol. 3 No.2 October 2016}

Further, these sessions promoted students' acquisition and prepare them to enter task stage. Finally, the result of speaking achievement and students' perception after using TBLT as approach proved that this approach is more effective and helpful to increase students' achievement and perception.

\section{CONCLUSION AND SUGGESTION}

\section{Conclusion}

The researcher concludes that the use of TBLT in teaching speaking significantly develops students' speaking skill. The conclusion is generated based on mean score of experimental group' posttest result (67.64) which is higher than mean score of control group' posttest result (56.08). Furthermore, the implementation of TBLT in teaching English in Indonesia's vocational schools can be treated as a better alternative in developing students' speaking skill although it is sometime mixed and modified in terms of application based on students' condition. Besides, TBLT is perceived as high by the students.

\section{Suggestion}

The researcher would like to recommend English teacher of SUPM under Ministry of Marine Affairs and Fisheries, especially SUPM Negeri Ladong, to apply TBLT in teaching speaking skill. It has been observed that the result of this approach on speaking test was significant. Furthermore, the researcher would like to suggest English teachers who want to use this approach to enhance students' vocabulary and grammar, and to intensify speaking practice to maximize the result of the approach. Finally, the research would like to suggest English teachers to use materials, tasks and tests that are closely related to students' knowledge and experiences. 
Wahidin : Applying Task-Based Language Teaching ... |155

\section{REFERENCES}

Alsagheer, A., Hasan, A. 2014.The effect of using task-based learning in teaching English on the oral performance of the secondary school students. International interdisciplinary journal of education. 32. 251.

Arikunto, S, 2006. Prosedur Penelitian: Suatu Pendekatan Praktek. Jakarta: PT. Rineka Cipta.

Bahrani, T. 2011. Speaking fluency: Technology in EFL context or social interaction in ESL context. Studies in Literature and Language, 22, $162-$ 168.

Boonkit, K. 2010. Enhancing the development of speaking skills for non-native speakers of English. Procedia Social and Behavioral Sciences, 22010, 1305-1309.

Dailey, A. 2009. Implementing Task-Based Language Teaching in Korean Classrooms Module 1 Assessment Task, July, 1-20.

Ellis, R. 2003. Task-Based Language Learning and Teaching. Oxford: Oxford University Press.

Heaton, J.B. 1989. Writing English Language Test. New Edition. USA: Longman.

Ho, P.V. P. \& Long, N. H. 2014. The Impact of Task-based Speaking Activities on English-Majored Freshmen's Oral Performance at Ba Ria-Vung Tau Teacher Training College. Journal of Science Ho Chi Minh City University, 3 11, 71-82.

Muhammadipour, M. \& Rashid, S, 2015. The impact of task-based instruction program on fostering ESL learners' speaking ability: A cognitive approach. Advances in Language and Literary Studies, 62, 143-126.

Sabil, M. 2013. Improving the students' speaking proficiency through Task-Based Language Teaching (A experimental Study at the Third Grade Students SMAN 1 Amali Kabupaten Bone). Unpublished Thesis. Makassar. Graduate Program UNM.

SUPM Ladong. 2010. Panduan Penilaian SUPM Ladong. SUPM Negeri Ladong.

Tabrizi, A. R. N \& Nasiri, M. 2011. The Effect of Using Task-Based Activities on Speaking Proficiency of EFL Learners. The Asian Conference on Education. 4. 333-345.

Willis, D \& Willis, J. 2007. Doing task-based Teaching. Oxford: Oxford University Press.

Zaremba, A. J. 2006. Speaking professionally. Canada: Thomson SouthWestern. 